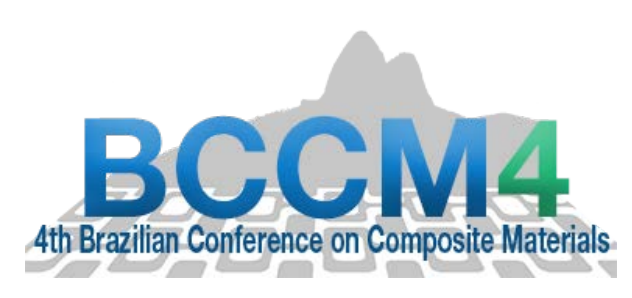

\title{
THERMAL PROPERTIES STUDY OF RECYCLED ESPRESSO COFFEE CAPSULES FOR BIOCOMPOSITE APPLICATION
}

\section{Anne Shayene Campos de Bomfim ${ }^{(1)}$, Herman Jacobus Cornelis Voorwald ${ }^{(1)}$, Maria Odila Hilário Cioffi ${ }^{(1)}$ and Kelly Cristina Coelho de Carvalho Benini( ${ }^{(1)}$}

(1) Department of Materials and Technology, São Paulo State University (UNESP), School of Engineering, Guaratinguetá, São Paulo, Brazil (12516-410). Fatigue and Aeronautical Materials Research Group.

https://doi.org/10.21452/bccm4.2018.14.01

\begin{abstract}
Solid plastic waste has been an environment problem with a lot of discussions in literature. The humanity needs to think about the future and be aware about its residues because only with this thinking will be possible to decrease environmental impacts and conserve natural resources. Espresso coffee capsules waste have grown in the last years because espresso machines provide an easily and quickly way to have a coffee time. This residue is difficult to recycling because it is composed of various materials. However the needs to decrease the impact caused by this waste influenced the thinking of researchers about applied this recycled polymer as matrix in polymeric biocomposites. In this context, the present work has the main objective of to separate the polypropylene (PP) that is the main component of the capsules, and carried out the mechanical recycling of this material to use it as a matrix of a biocomposites reinforced with natural fibers. In order to understand thermal degradation, melting point and crystallization point, the recycled material was characterized before and after recycling process by thermogravimetric (TGA) and differential scanning calorimetry (DSC) analysis and compared with a virgin PP. TGA shows no significant thermal stability loss with PP thermal degradation beginning at $280{ }^{\circ} \mathrm{C}$ for virgin PP and $275^{\circ} \mathrm{C}$ for capsules and recycled material. DSC shows melting point and crystallization point respectively at $163{ }^{\circ} \mathrm{C}$ and $114^{\circ} \mathrm{C}$ for virgin $\mathrm{PP}, 163{ }^{\circ} \mathrm{C}$ and $116^{\circ} \mathrm{C}$ for capsules and $163{ }^{\circ} \mathrm{C}$ and $114{ }^{\circ} \mathrm{C}$ for recycled material. These results demonstrate the viability of mechanical recycling of plastic capsules for future reuse in new products.
\end{abstract}

\section{INTRODUCTION}

The need to decrease the environment impacts has increased the solutions in recycling and reuse of materials. The plastic solid waste is one of the major environmental problems because of the 
large production and the degradation time [1]. Plastics are the major contributor to municipal and industrial residues and their recycling is a sustainable way to improve the humanity future through its reuse in new products avoiding the amount of waste in sanitary landfills [2].

The recycling process can be mechanical, chemical or across to the recover energy by incineration [3]. Mechanical recycling allows direct material recuperation to reuse in new products manufacturing [2], the waste is separated, washed and grinding to become a new raw material [4].

The espresso coffee capsules is an emerging solid waste because the advantage of their practicality with coffee variations done in a quickly way and the decrease price of espresso domestic machines. The research of Consórcio Pesquisa Café (2015) shows that between 2014 and 2019 the coffee capsules market can almost triple with a volume of 6 thousand tons to 16 thousand tons [5]. However, these wastes cannot be recycling in whatever place because the materials variation like plastic, coffee grounds and aluminium, influencing the sanitary landfills overcrowding [6]. Then this residue needs more attention, like selective collection to material separation and recycling.

Nowadays there are studies about environment friendly polymers to be used as polymeric matrix in biocomposites with non-structural applications [7]. These biocomposites can have biodegradable polymers [8], natural fibers [9] or recycled polymers [10] to be considered a sustainable material. Composites with recycled polymeric matrix are getting more attention in literature because the use of waste materials help the environmental preservation [1].

In this context, the objective of this work was the recycling of espresso coffee capsules plastic waste and analysed the thermal properties through thermogravimetric analysis (TGA) and differential scanning calorimetry (DSC) to apllication in a biocomposite reinforced with natural fibers. This results were compared to virgin PP and the capsules before recycling to ensure plastic recycled thermal stability as a polymeric matrix.

\section{EXPERIMENTAL}

\section{Materials}

The plastic waste used was Dolce Gusto espresso coffee capsules. All varieties of capsules were collected after consumption, like coffee varieties, cappuccino, chocolates and tea. After that, they were opened to components separation and washing. The plastic package is composed by a laminated sheet sealing the package, a plastic film (only in coffee capsules), coffee powder or other variety and aluminium foil on a plastic filter. In this work only the plastic package and the filter were recycled because both are made of polypropylene (PP).

The polypropylene Homopolymer H103 manufactured by Braskem was also characterized as a control and used just as a base to compare the PP behaviour on the capsules and after recycling. The follow three samples were analysed: virgin polypropylene homopolymer H103 (PP), polypropylene capsules (PPC) and polypropylene capsules recycled (PPR).

\section{Mechanical recycling methodology}

Cleaned plastic package and plastic filter were firstly ground in a knife mill model RONE then the material was grounded again in a mill model WILLYE in order to obtain small granules. After that, the granules were dried in an oven at $60{ }^{\circ} \mathrm{C}$ for $24 \mathrm{~h}$. The dried granules were melted in a thermokinetic mixer with the objective to carry out the same process which will be used for the biocomposites obtaining. 


\section{Thermogravimetric analysis (TGA)}

Approximately $10 \mathrm{mg}$ of PP, PPC and PPR samples were analysed in a SII Nanotechnology INC equipment, model Exstar 6000, TG/DTA 6200 series, using a temperature range from $30^{\circ} \mathrm{C}$ to $800{ }^{\circ} \mathrm{C}$, at a $10^{\circ} \mathrm{C} / \mathrm{min}$ heating rate, operating with a nitrogen flow of $100 \mathrm{~mL} / \mathrm{min}$.

\section{Differential scanning calorimetry (DSC)}

Approximately $7 \mathrm{mg}$ of PP, PPC and PPR samples were analysed in a DSC Q20 TA Instruments equipment, using dual scan technique with a temperature range from $-30{ }^{\circ} \mathrm{C}$ to $250{ }^{\circ} \mathrm{C}$, at a 10 ${ }^{\circ} \mathrm{C} / \mathrm{min}$ heating rate and a $20^{\circ} \mathrm{C} / \mathrm{min}$ cooling rate, operating with a nitrogen flow of $40 \mathrm{~mL} / \mathrm{min}$.

\section{RESULTS AND DISCUSSION}

\subsection{TGA}

TGA and DTG curves of PP, PPC and PPR samples are presented at Figure 1 and the thermal parameters determined from this curves are presented at Table 1.

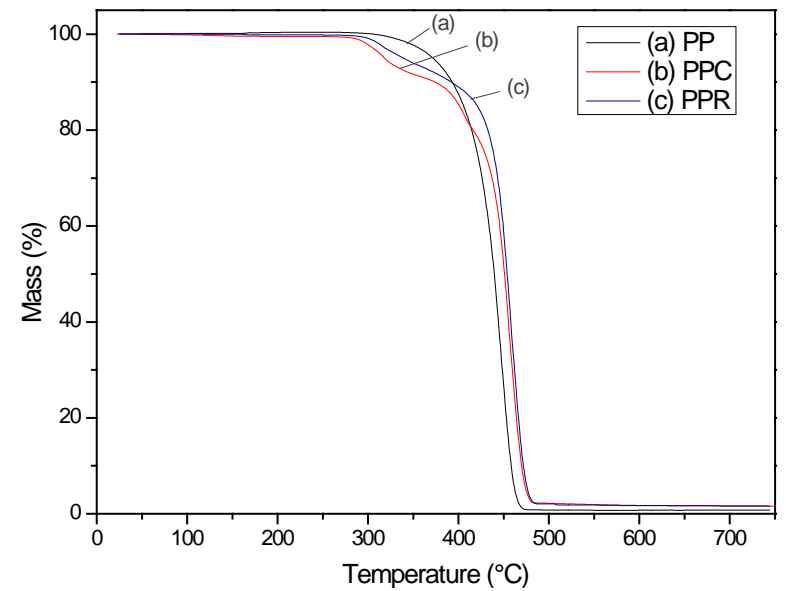

(a)

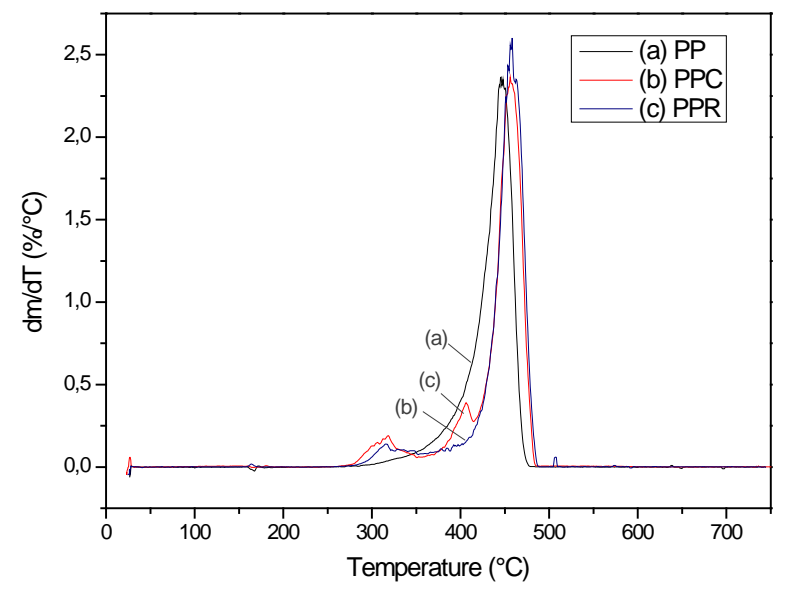

(b)

Figure 1 : (a) TGA and (b) DTG curves of PP, PPC and PPR samples.

According to presented results it is possible to observe that PP presents only one thermal event with a degradation temperature beginning at $280{ }^{\circ} \mathrm{C}$, Tonset at $402^{\circ} \mathrm{C}$ and no significant residue at $700{ }^{\circ} \mathrm{C}$. This similar behaviour of PP thermal degradation was observed by GOLEBIEWSKI and GALESKI [11], and PARPARITA et al. [12]. On the other hand, PPC presents tree thermal events, probably because the capsules manufacturing process. Degradation temperature beginning at 275 ${ }^{\circ} \mathrm{C}$, $\mathrm{T}_{\text {onset }}$ at $289^{\circ} \mathrm{C}$ and $1.6 \%$ of residue at $700{ }^{\circ} \mathrm{C}$ was observed probably due to fixed carbons and additives, like stabilizers, pigments and antioxidants. The presence of two more peaks in PPC samples indicates there is another material degrading with the original polymer (PP), suggesting that the capsules may have some contaminant, like other polymer or substance. 
Table 1: TGA parameters for PP, PPC and PPR samples

\begin{tabular}{cccccc}
\hline Samples & $\begin{array}{c}\Delta \mathrm{T} \\
\left({ }^{\circ} \mathrm{C}\right)\end{array}$ & $\begin{array}{c}\mathrm{T}_{\text {onset }} \\
\left({ }^{\circ} \mathrm{C}\right)\end{array}$ & $\begin{array}{c}\mathrm{T}_{\text {peak }} \\
\left({ }^{\circ} \mathrm{C}\right)\end{array}$ & $\begin{array}{c}\text { Weight loss } \\
(\%)\end{array}$ & $\begin{array}{c}\text { Residue at } \\
700{ }^{\circ} \mathrm{C}(\%)\end{array}$ \\
\hline PP & $280-480$ & 402 & 446 & 99.2 & 0.8 \\
\hline \multirow{3}{*}{ PPC } & $275-360$ & 289 & 317 & 9.0 & \\
& $360-415$ & 386 & 405 & 10.0 & 1.6 \\
& $415-488$ & 439 & 456 & 78.0 & \\
\hline \multirow{2}{*}{ PPR } & $275-360$ & 294 & 315 & 7.0 & 1.6 \\
& $360-490$ & 433 & 457 & 91.0 & \\
\hline
\end{tabular}

Recycling process probably caused some thermal changes in polymers. PPR sample presents two thermal events beginning at $275^{\circ} \mathrm{C}, \mathrm{T}_{\text {onset }}$ at $294^{\circ} \mathrm{C}$ and also $1.6 \%$ of residue at $700{ }^{\circ} \mathrm{C}$. This result suggest that the second event presents in PPC specimen disappear after recycling, probably because the material was exposed to thermo-mechanical degradation due to submission to high shear forces and high temperatures during recycling $[1,14]$.

\subsection{DSC}

DSC curves of second heating and cooling for PP, PPC and PPR samples are presented at Figure 2 and Figure 3, respectively. The parameters determined from this curves are presented at Table 2. In the present work only the second heating and cooling were considered to determine the melting and crystallization points since the first heating is carried out in order to cleaning the thermal history of the samples [15].

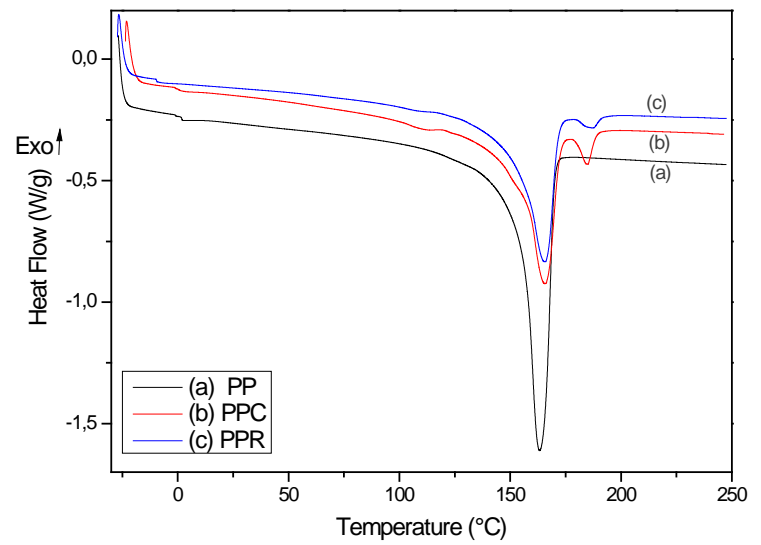

(a)

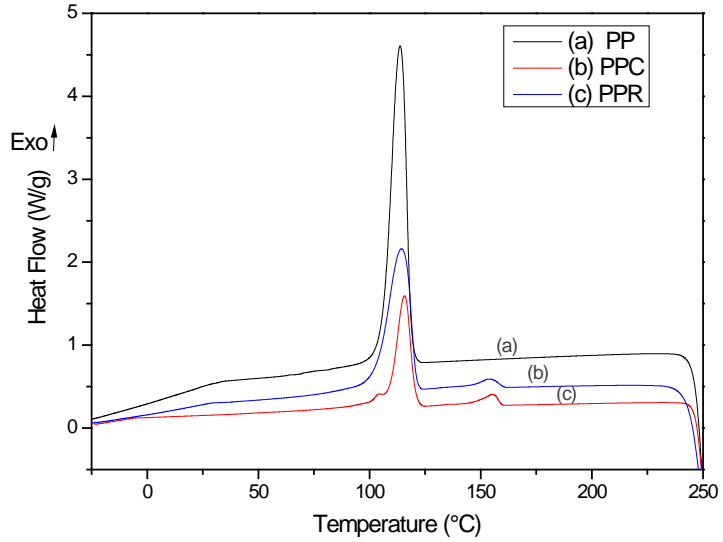

(b)

Figure 2 - (a) Second Heating and (b) Colling curves for PP, PPC and PPR samples.

According to data, PP sample presents one endothermic peak with melting temperature $\left(T_{\mathrm{m}}\right)$ at $163^{\circ} \mathrm{C}$ and glass transition temperature $\left(\mathrm{T}_{\mathrm{g}}\right)$ at $1.8^{\circ} \mathrm{C}$, and one exothermic peak with crystallization temperature $\left(\mathrm{T}_{\mathrm{c}}\right)$ at $114^{\circ} \mathrm{C}$. In literature, a commercial polypropylene presents the same behaviour [15-17]. On the other hand, PPC sample presents two endothermic peaks $\left(\mathrm{T}_{\mathrm{m} 1}\right.$ and $\left.\mathrm{T}_{\mathrm{m} 2}\right)$ and $\mathrm{T}_{\mathrm{g}}$ at 
$0.4{ }^{\circ} \mathrm{C}$ during the second heating, and three exothermic peaks $\left(\mathrm{T}_{\mathrm{c} 1}, \mathrm{~T}_{\mathrm{c} 2}\right.$ and $\left.\mathrm{T}_{\mathrm{c} 3}\right)$ at the cooling, but $\mathrm{T}_{\mathrm{c} 3}$ is just a shoulder suggesting some PP crystal needed a little more temperature to crystalize. This difference between PP and PPC, such as the presence of one more melting and crystallization peaks suggest there is a polymer mixture in the capsule package, as observed in TGA analysis. The other polymer could be polyamide 11 with melting temperature between $180-200{ }^{\circ} \mathrm{C}$ and thermal degradation $439-451^{\circ} \mathrm{C}[18,19]$.

Table 2: DSC parameters for PP, PPC and PPR samples

\begin{tabular}{|c|c|c|c|c|c|c|c|c|c|c|c|}
\hline Samples & $\begin{array}{l}\mathrm{T}_{\mathrm{m} 1} \\
\left({ }^{\circ} \mathrm{C}\right)\end{array}$ & $\begin{array}{l}\Delta \mathrm{H}_{1} \\
(\mathrm{~J} / \mathrm{g})\end{array}$ & $\begin{array}{l}\mathrm{T}_{\mathrm{m} 2} \\
\left({ }^{\circ} \mathrm{C}\right)\end{array}$ & $\begin{array}{l}\Delta \mathrm{H}_{2} \\
(\mathrm{~J} / \mathrm{g})\end{array}$ & $\begin{array}{c}\mathrm{T}_{\mathrm{c} 1} \\
\left({ }^{\circ} \mathrm{C}\right)\end{array}$ & $\begin{array}{c}\Delta \mathrm{H}_{\mathrm{c} 1} \\
(\mathrm{~J} / \mathrm{g})\end{array}$ & $\begin{array}{c}\mathrm{T}_{\mathrm{c} 2} \\
\left({ }^{\circ} \mathrm{C}\right)\end{array}$ & $\begin{array}{l}\Delta \mathrm{H}_{\mathrm{c} 2} \\
(\mathrm{~J} / \mathrm{g})\end{array}$ & $\begin{array}{c}\mathrm{T}_{\mathrm{c} 3} \\
\left({ }^{\circ} \mathrm{C}\right)\end{array}$ & $\begin{array}{l}\Delta \mathrm{H}_{\mathrm{c} 3} \\
(\mathrm{~J} / \mathrm{g})\end{array}$ & $\begin{array}{c}\mathrm{T}_{\mathrm{g}} \\
\left({ }^{\circ} \mathrm{C}\right)\end{array}$ \\
\hline PP & 163 & 98 & - & - & 114 & -97 & - & - & - & - & 1.8 \\
\hline PPC & 165 & 58 & 185 & 4 & 155 & -6 & 116 & -52 & 99 & -5 & 0.4 \\
\hline PPR & 165 & 59 & 187 & 2 & 154 & -3 & 114 & -64 & - & - & -9.6 \\
\hline
\end{tabular}

After recycling process is possible to observe that PPR sample presents the same PPC endothermic peaks, at the same temperature, but a significant decrease in the values of $T_{g}$. During the cooling only two exothermic peaks were observed at the same temperatures of the first two crystallization peaks of PPC, indicating that the shoulder presents in PPC sample disappears after recycling process, confirming it was some PP crystal taking more temperature to crystalize.

\section{CONCLUSION}

Thermal analysis shows espresso coffee capsules plastic waste can be mechanical recycled to biocomposites application. There is not significant thermal stability loss, difference melting and crystallization temperatures comparing with virgin PP. Degradation temperature and melting temperature proves that the recycled material can be injected to obtain tensile and impact specimens to mechanical studies and future application in new products.

As a plastic residue it is not possible to known all properties of this polypropylene package. This fact is emphasis in the TGA and DSC curves with the presence of non-expected peaks probably due to contaminants of capsules manufacturing. But it not interferes in the good result of capsules recycling and biocomposites manufacturing.

\section{REFERENCES}

[1] SINGH, N. et al. Recycling of plastic solid waste: A state of art review and future applications. Composites Part B, v. 115, p. 409-422, 2017.

[2] HAMAD, K.; KASEEM, M.; DERI, F. Recycling of waste from polymer materials: An overview of the recent works. Polymer Degradation and Stability, v. 98, n. 12, p. 2801-2812, 2013.

[3] SPINACÉ, M. A. DA S.; DEPAOLI, M. A. A tecnologia da reciclagem de polímeros. Química Nova, v. 28, n. 1, p. 65-72, 2005.

[4] RAGAERT, K.; DELVA, L.; VAN GEEM, K. Mechanical and chemical recycling of solid plastic waste. Waste Management, v. 69, p. 24-58, 2017.

[5] EUROMONITOR. Tendências do Mercado de CaféAssociação Brasileira da Indústria de Café (ABIC). [s.l: s.n.]. Disponível em: 
$<$ http://consorciopesquisacafe.com.br/arquivos/consorcio/consumo/Tendencia_do_Mercado_de_Cafe__2015_1.pdf>. Acesso em: 4 set. 2017.

[6] OGLOBO. Pesquisas inéditas mostram que reciclagem de cápsulas de café é problemática no Brasil. Disponível em: <https://oglobo.globo.com/sociedade/ciencia/meio-ambiente/pesquisas-ineditasmostram-que-reciclagem-de-capsulas-de-cafe-problematica-no-brasil-20660567>. Acesso em: 29 ago. 2017.

[7] MANCINO, A.; MARANNANO, G.; ZUCCARELLO, B. Implementation of eco-sustainable biocomposite materials reinforced by optimized agave fibers. Procedia Structural Integrity, v. 8, n. 2017, p. 526-538, 2018.

[8] GURUNATHAN, T.; MOHANTY, S.; NAYAK, S. K. A review of the recent developments in biocomposites based on natural fibres and their application perspectives. Composites Part A, v. 77, p. 125, 2015.

[9] LEMOS, A. L. DE et al. Biocomposites reinforced with natural fibers : thermal, morphological and mechanical characterization. Revista Matéria, p. 8-10, 2017.

[10] LAADILA, M. A. et al. Green synthesis of novel biocomposites from treated cellulosic fibers and recycled bio-plastic polylactic acid. Journal of Cleaner Production, v. 164, p. 575-586, 2017.

[11] MEI, L. H.; OLIVEIRA, N. Caracterização de um compósito polimérico biodegradável utilizando Poli ( $\varepsilon$-caprolactona) e borra de café. Polímeros, v. 27, p. 99-109, 2017.

[12] GOLEBIEWSKI, J.; GALESKI, A. Thermal stability of nanoclay polypropylene composites by simultaneous DSC and TGA. Composites Science and Technology, v. 67, n. 15-16, p. 3442-3447, 2007.

[13] PARPARITA, E. et al. TG/FT-IR/MS study on thermal decomposition of polypropylene/biomass composites rp a rit. Polymer Degradation an Stability, v. 109, p. 13-20, 2014.

[14] SANCHEZ, F. A. C. et al. Polymer Recycling in an Open-Source Additive Manufacturing Context: Mechanical Issues. Additive Manufacturing, v. 17, p. 87-105, 2017.

[15] AMINTOWLIEH, Y. et al. Effects of processing variables on polypropylene degradation and long chain branching with UV irradiation. Polymer Degradation and Stability, v. 104, n. 1, p. 1-10, 2014.

[16] MAJEWSKY, M. et al. Determination of microplastic polyethylene (PE) and polypropylene (PP) in environmental samples using thermal analysis (TGA-DSC). Science of the Total Environment, v. 568, p. 507-511, 2016.

[17] OLIVEIRA, R. A. DE. Comportamentos, térmico e mecânico, de compósitos de polipropileno e resíduo da hidrólise enzimática do bagaço de cana de açúcar. 2014. São Paulo State University (UNESP). 2014.

[18] OLIVER-ORTEGA, H. et al. Evaluation of thermal and thermomechanical behaviour of bio-based polyamide 11 based composites reinforced with lignocellulosic fibres. Polymers, v. 9, n. 10, 2017.

[19] HOCKER, S. J. A. et al. Graphene oxide reduces the hydrolytic degradation in polyamide-11. Polymer (United Kingdom), v. 126, p. 248-258, 2017. 